\title{
Narciso reflejado: trabajar con la imagen propia en un contexto de confinamiento. Práctica artística con un grupo de estudiantes de Bellas Artes
}

\author{
Reflected Narcissus: working with one's image in a confined \\ environment. Artistic activity with a group of Fine Arts students
}

\section{Francisca Beneyto Ruiz}

Facultad de Bellas Artes.

Universidad Complutense de Madrid.

fbeneyto@ucm.es
Recibido: 10/09/2020 Revisado: 18/10/2020

Aceptado: 09/12/2020 Publicado: 14/12/2020

\section{Resumen}

A continuación, presento la descripción de una actividad plástica realizada por un grupo de estudiantes de primero de Bellas Artes de la Universidad Complutense durante el confinamiento vivido en el segundo cuatrimestre del curso 2019-2020. Esta actividad gira en torno al reflejo, el espejo y el mito de Narciso y se desarrolla con los medios impuestos por una situación muy restrictiva de encierro e incertidumbre.

\section{Abstract}

Below I present the description of an activity by a group of first-year students of Fine Arts from the Complutense University of Madrid during quarantine in the second semester of the 2019-2020 academic year. The activity revolves around the reflection, the mirror and the Narcissus myth, and takes place with the means imposed by the very restrictive situation of confinement and uncertainty.

\section{Sugerencias para citar este artículo,}

Beneyto Ruiz, Francisca, (2020). Narciso reflejado: trabajar con la imagen propia en un contexto de confinamiento. Práctica artística con un grupo de estudiantes de Bellas Artes. Tercio Creciente (Monográfico extraordinario IV), (pp. 109-131), https://dx.doi.org/10.17561/rtc.extra4.5733

BENEYTO RUIZ, FRANCISCA. Narciso reflejado: trabajar con la imagen propia en un contexto de confinamiento. Práctica artística con un grupo de estudiantes de Bellas Artes. Tercio Creciente (Monográfico extraordinario IV), diciembre 2020, pp. 109-131, https://dx.doi.org/10.17561/rtc.extra4.5733 


\author{
Palabras clave \\ Mito de Narciso, reflejo, espejo, práctica artística \\ Keywords \\ Narcissus myth, reflection, mirror, artistic practice
}

\title{
Agradecimientos
}

Dicen que en una situación complicada se conoce mejor a las personas. Yo no conocía al grupo con el que tuve la suerte de coincidir en el segundo cuatrimestre de 2020, pero estoy segura de que ya venían con una base extraordinaria y así lo demostraron durante el encierro al que nos vimos sometidos. Gracias grupo 8.

\section{Sugerencias para citar este artículo,}

Beneyto Ruiz, Francisca, (2020). Narciso reflejado: trabajar con la imagen propia en un contexto de confinamiento. Práctica artística con un grupo de estudiantes de Bellas Artes. Tercio Creciente (Monográfico extraordinario IV), (pp. 109-131), https://dx.doi.org/10.17561/rtc.extra4.5733

BENEYTO RUIZ, FRANCISCA. Narciso reflejado: trabajar con la imagen propia en un contexto de confinamiento. Práctica artística con un grupo de estudiantes de Bellas Artes. Tercio Creciente (Monográfico extraordinario IV), diciembre 2020, pp. 109-131, https://dx.doi.org/10.17561/rtc.extra4.5733 


\section{Contexto de la práctica}

La actividad que presento a continuación se desarrolla dentro de la asignatura Análisis de la Forma, la cual está dedicada a que los estudiantes aprendan y adquieran herramientas para la comprensión de la imagen, sobre todo la artística. En ella, hemos trabajado a lo largo de este cuatrimestre los principales elementos del lenguaje visual a través de diferentes técnicas relacionadas con el dibujo. La asignatura tiene varios objetivos dirigidos al saber hacer y al saber mirar, dado que para un estudiante de Bellas Artes tan importante es tener recursos para crear como para establecer un análisis crítico. Este es pues, el enfoque de la asignatura, aunque se haya cruzado en nuestro camino el COVID-19.

Para llevar a cabo esta tarea docente, planifiqué la materia en cuatro bloques cuyas temáticas han sido: el Espacio, el Objeto, el Cuerpo y la Naturaleza. Cada uno de estos bloques ha estado compuesto por una serie de ejercicios donde se han trabajado al mismo tiempo aspectos formales como el color, la estructura, o la composición y aspectos conceptuales como la poética de la representación, la obra de artistas o conceptos de fondo.

El primer bloque que trabajamos fue el relacionado con el espacio. Este bloque nos sirvió para conocernos todos y en mi caso, también me valió para saber el nivel de destreza y habilidades que traían los estudiantes. A pesar de que el nivel era desigual, había un grupo grande de alumnas y alumnos que venía con una base muy fuerte, lo cual significaba que no había que tirar mucho del conjunto para que avanzasen, dado que ya se veía que en la mayoría de ellos había muchas horas de dibujo a sus espaldas.

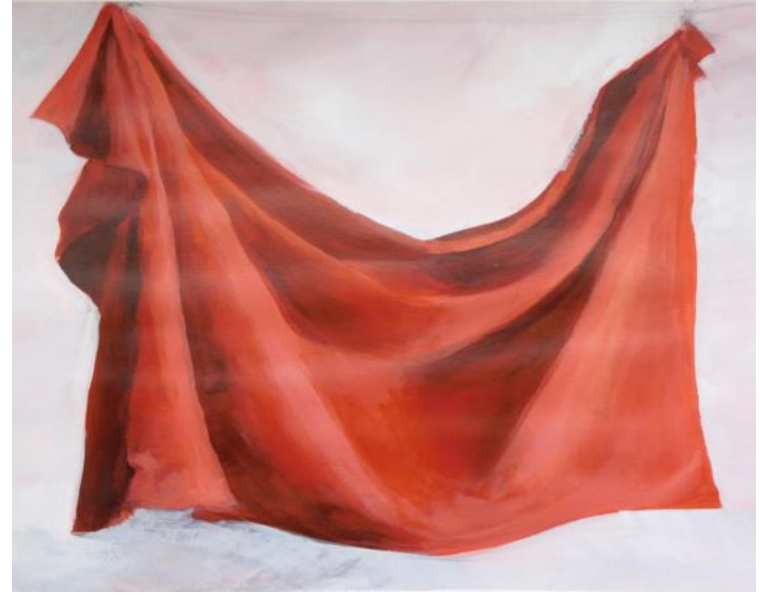

Paloma de Miguel. Marzo 2020. Acrílico. Tejido.

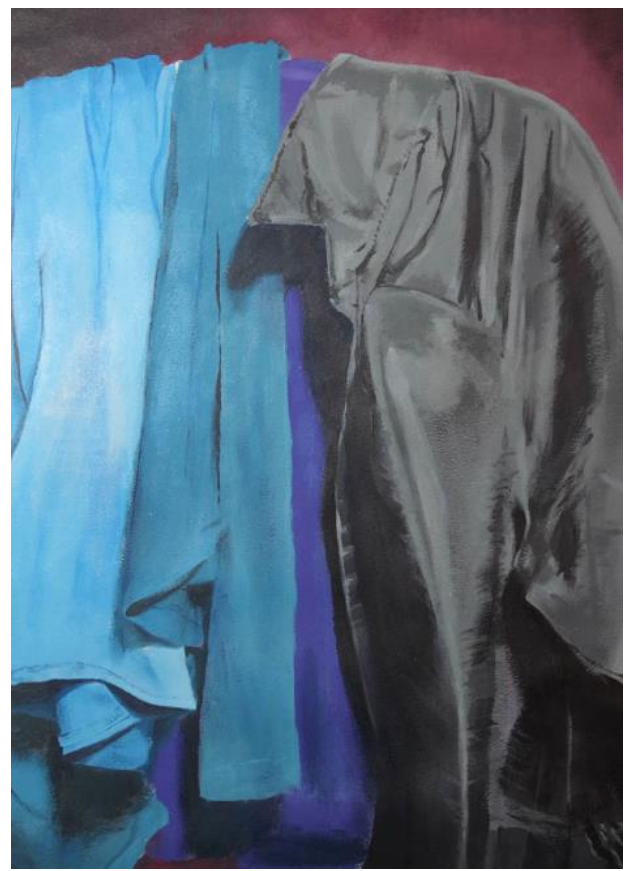

Lydia Gordaliza. Marzo 2020. Acrílico. Tejido. 


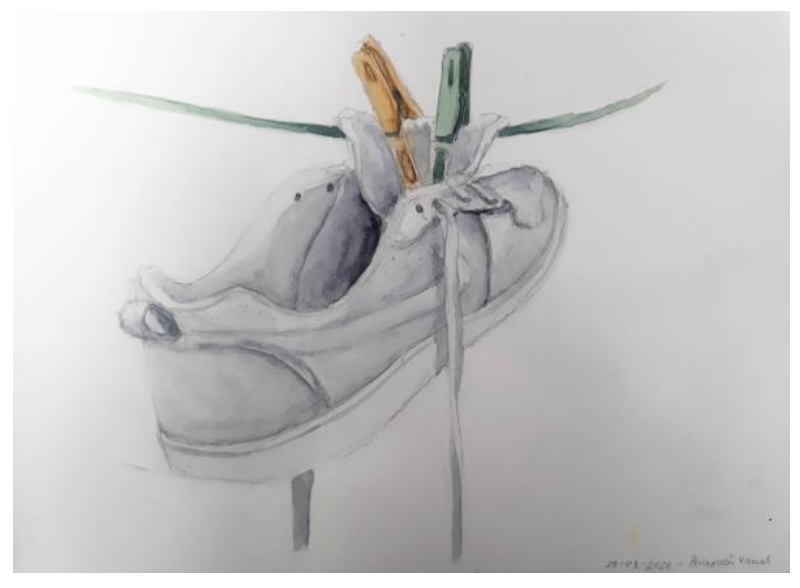

Paula Pérez. Marzo 2020. Acuarela. Objetos.

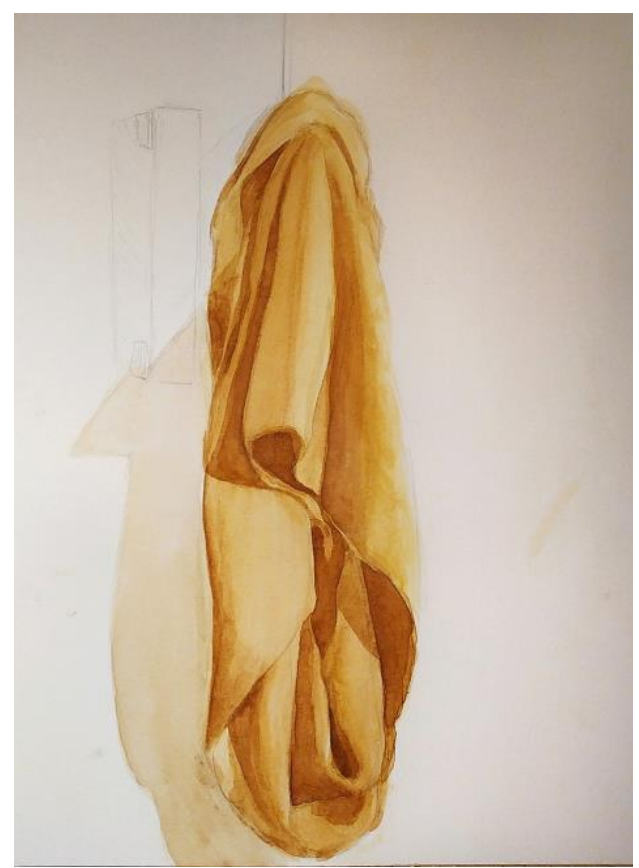

Mora Romero. Marzo.2020. Acuarela. Tejido.

Tras este primer bloque del espacio, abordamos el bloque del objeto. Comenzamos haciendo dos ejercicios relacionados con el tema, pero estos se vieron interrumpidos debido a que tuvimos que abandonar la facultad de un día para otro debido al peligro de contagio por el COVID-19. En un principio parecía que íbamos a regresar en unos días, por lo que la mayoría dejó sus trabajos en el aula a la espera de que volviéramos a la misma situación que habíamos dejado tras la marcha. Ninguno pensábamos que ya no nos íbamos a encontrar y que terminaríamos el curso cada uno en su casa.

En esos primeros días los profesores trasladamos la docencia al Campus Virtual, enviando material y pautas de trabajo sin mucha planificación, dado que lo que teníamos ante nosotros era una absoluta incertidumbre. Cuando ya se decretó que la Universidad pasaba a la modalidad on line, tuvimos que readaptar la asignatura a esta nueva condición.

Tras superar la confusión de los primeros momentos, pude pensar en reconducir la planificación de la materia y adaptarla a una situación donde cada uno pudiera trabajar desde su casa. Mientras tanteaba posibilidades, comprobé que el encierro propiciaba la reflexión de uno mismo con más calma, así que me decidí a utilizar esta circunstancia para llevarlo al conjunto de trabajos que aquí presento. 


\section{Primeros planteamientos}

Como he comentado anteriormente, trabajábamos el bloque del objeto cuando nos sorprendió la crisis sanitaria. Varios estudiantes cuyas familias viven fuera de Madrid, se marcharon a sus ciudades antes de que cerraran el tránsito entre provincias. Esto supuso que en algunos casos el material de trabajo con el que iban a contar a partir de ese momento sería demasiado escaso para abordar la asignatura. Además, esto se unió a que no se podía salir de casa debido al Estado de Alarma decretado por el Gobierno el 14 de marzo, por lo que el proceso de enseñanza y aprendizaje se presentaba con limitaciones importantes.

En esta nueva situación se terminó de trabajar el bloque del objeto y pasamos al bloque relacionado con el cuerpo.

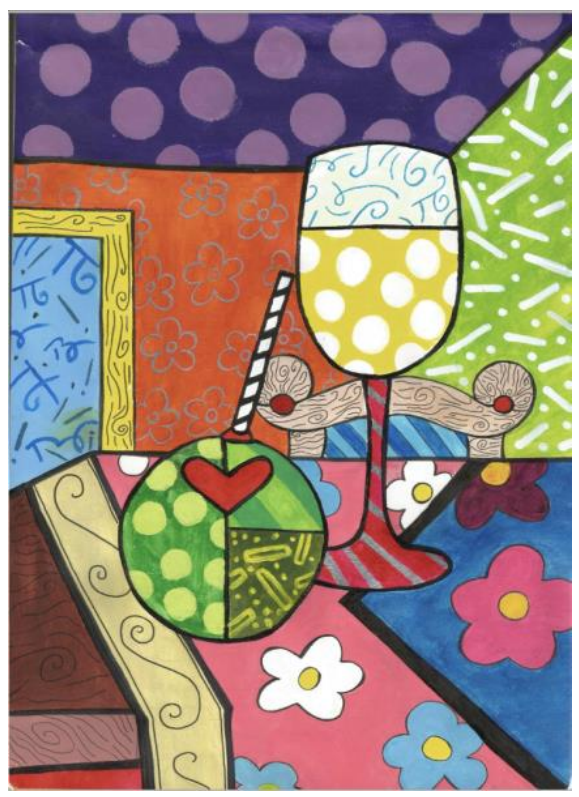

Jesus Rey. Marzo.2020. Objetos. Acrílico.

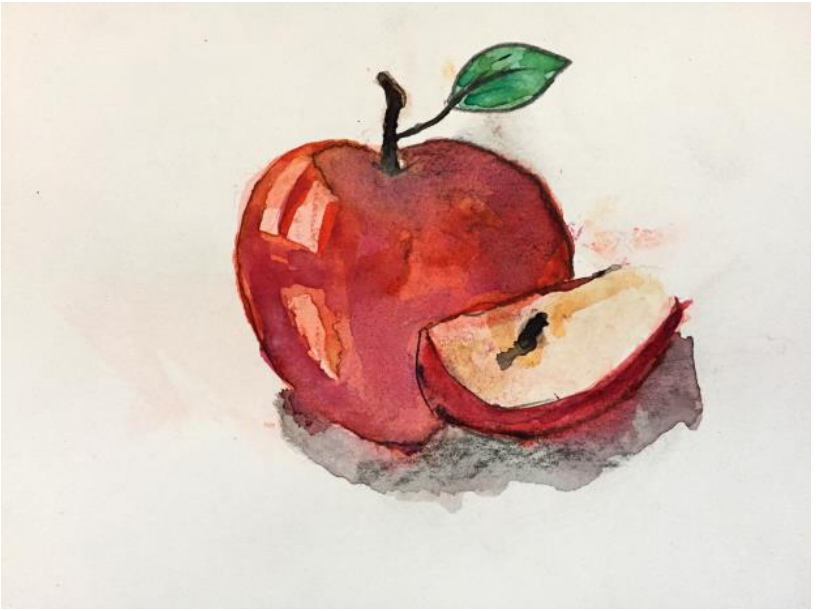

Nerea Sánchez. Marzo.2020. Objetos. Acuarela.

Aunque el marco era complejo, había tenido suerte de que el confinamiento coincidiera con el bloque dedicado al cuerpo, pues mi idea de enfocar los ejercicios hacia una auto reflexión se adecuaba perfectamente.

A los objetivos generales mencionados anteriormente, añadí otros específicos relacionados con el estudio de la identidad, la comprensión del espejo como catalizador de conceptos e impulsor de recursos plásticos y el refuerzo de un pensamiento crítico a través de referencias teóricas y artísticas. 
En un escenario de docencia presencial y sin problemas añadidos, cada uno de los bloques se compone de una presentación de la nueva unidad de trabajo, lecturas que apoyan las ideas del bloque y la propuesta de varios ejercicios que ponen en práctica tanto cuestiones formales como conceptuales. Dado que la docencia pasó íntegramente a impartirse de manera on line, decidí introducir algunos recursos complementarios con el fin de diversificar el proceso. A la presentación del bloque, las lecturas y las pautas de trabajo, añadí un foro de debate que permitiese a los alumnos y alumnas expresar sus ideas sin necesidad de utilizar un lenguaje demasiado académico que restara frescura. En cursos anteriores, nunca había tenido éxito con los foros, pues las intervenciones eran escasas y estos pronto morían en el olvido. Sin embargo, el foro planteado en esta ocasión suscitó bastante interés; yo creo que porque era un espacio de expresión común que nos unía a todos de alguna manera en esta extraña situación de aislamiento.

Expongo a continuación el modo en que concebí el bloque, los materiales que facilité, los recursos digitales empleados y las pautas sobre las que los estudiantes trabajaron. Una vez planteado el conjunto, presento una selección de los resultados y propongo unas conclusiones sobre la experiencia didáctica vivida.

Para comenzar les subí al campus una presentación elaborada con textos y referencias de artistas que han trabajado con el espejo como medio de expresión plástica y conceptual, ya que este objeto plantea unas posibilidades muy potentes en esta dirección.

Para la presentación busqué un texto de inicio que fuera lo suficientemente claro y directo para que los estudiantes se sintieran implicados. Tras valorar varios con los que ya había trabajado, escogí un párrafo del libro Últimas tendencias del arte, escrito por Yayo Aznar y Joaquín Martínez, el cual es una apelación al lector/a para que reconsidere su relación con la imagen

Tenemos que empezar a aceptar que las imágenes que nos rodean, incluidas las producidas por la Historia del Arte, son imágenes que construyen nuestras identidades, que nos sitúan en un papel concreto, en un "yo mismo" con el que ya, para siempre, tendremos que identificarnos. Es el niño lacaniano* que cuando se reconoce finalmente en un espejo, ya no se ve a sí mismo (ese sí mismo que menciona Saramago en el "Ensayo sobre la ceguera" cuando dice eso que hay dentro de mí que no sé lo que es, ése soy yo), sino que ya ve una construcción social, no ve lo que es, sino lo que "debe ser", lo que los otros (empezando por sus padres) quieren que sea. Y las mujeres han estado, a lo largo de la historia, permanentemente rodeadas de esas imágenes. Son esas imágenes que nos han situado o bien como sumisas, castas y fieles compañeras de los hombres, o bien todo lo contrario, como ídolos de perversidad muy peligrosos. O somos santas, o somos putas y asesinas. Somos el pecado, somos sirenas o vampiros, somos Salomé pidiendo la cabeza del Bautista... somos hijas de Lilith. Una vez aceptada la construcción interesada y dominadora de la identidad femenina por parte de la Historia del Arte, ya nunca más podremos volver a pensar que las representaciones, las obras son universales 
y neutras, como se ha sostenido durante mucho tiempo, y tendremos que verlas como lo que son, es decir, jerarquizadas, etnocéntricas y sexistas. (Aznar, Martínez. 2009: 193).

A este texto lo acompañaba como digo, una propuesta de artistas que utilizan el reflejo y el espejo en su obra. En una situación de no confinamiento esta presentación se habría puesto en clase y habríamos ido hablando sobre los artistas y sus obras, sus intereses, propuestas etc. Aunque en mi caso me gusta comenzar las presentaciones enmarcando los temas y estableciendo un contexto de lo que vamos a ver, en seguida prefiero que los estudiantes participen activamente con sus comentarios, pues creo que es muy enriquecedor alternar argumentos que orienten el tema con otros que interpreten y ofrezcan distintos puntos de vista.

En este caso, consideré que la ocasión se prestaba a que cada uno desde su casa ofreciese una visión personal del tema a partir de un texto escrito, pues así podría conocer mejor su capacidad de análisis, comprensión y comunicación. Así pues, les propuse como práctica que por un lado revisasen con profundidad la mencionada presentación y los artistas que la componen y por otro que leyeran los textos El espejo como no-lugar (1964-2010) escrito por Tonia Raquejo y el mito de Narciso que se encuentra dentro del libro "Los mitos griegos" cuyo autor es Roger Graves.

A estas lecturas obligatorias propuse otras complementarias para que ahondasen más en el tema si estaban interesados. Una de esas lecturas es el famoso texto de Lacan El estadio del espejo como formador de la función del yo [je] tal como se nos revela en la experiencia Psicoanalítica, pues si bien ofrece unas reflexiones de base sobre el tema, también es mencionado tanto en el pasaje del libro Últimas tendencias del arte como en el texto El espejo como no-lugar (1964-2010).

Otra lectura de apoyo que les ofrecí leer para tener más referencias sobre el tema fue El retrato de Dorian Grey del escritor irlandés Oscar Wilde, pues el relato también trata la relación del sujeto con su reflejo desde un punto de vista narcisista, lo cual les ayudaría a complementar la lectura del mito.

Todas estas referencias plantean la relación del reflejo con la construcción de la identidad, ya sea a través del contacto con uno mismo, con el otro o a través de las imágenes del arte. Si bien cada texto es de un género, época y lugar muy diferentes, la problemática del vínculo con el Yo es el nudo principal de todos ellos. Si los tiempos hubieran sido otros les habría pedido que incluyeran en su análisis todos estos textos, pero como he comentado solo les propuse como lectura obligatoria dos de ellos. Así pues, consideré que el texto de Tonia Raquejo y el mito de Narciso eran las mejores opciones, puesto que en ambos se establece de manera muy clara la tensión que surge entre uno mismo, el conocimiento, el deseo y la belleza (Raquejo. 2012:243).

Paralelamente a estas lecturas y el trabajo del análisis, les pedí participar en un foro donde expresaran a partir de un tema que les concierne, las ideas que iban adquiriendo. Como he mencionado anteriormente, el foro tuvo mucha aceptación. Si 
bien es cierto que se trataba de un elemento más de trabajo dentro del bloque y la participación era necesaria, ellos lo abordaron a mi juicio, desde una sinceridad muy significativa, pues claramente no solo participaban porque yo lo había pedido, sino porque el tema les interesaba y tenían algo que decir.

\title{
El tema del foro que propuse fue el siguiente:
}

\begin{abstract}
“Instagram es una herramienta que para muchas personas es un modo de poner a prueba su propia imagen, valorar su aceptación y por qué no, construir aquella imagen que más les conviene. ¿consideras que el trabajo de modelado de la imagen que se realiza en Instagram ayuda a entenderse y conocerse mejor, dado que esta labor es más compleja y profunda que la sola presentación de la apariencia física? ¿o por el contrario crees que afianza un narcisismo no solo físico? (en los perfiles encuentras quien expone su cuerpo pero también quien expone dibujos, a su familia, momentos divertidos o bonitos, tatuajes...) Dicho de otro modo ¿cuál crees que es la función que juega Instagram en nuestra identidad?
\end{abstract}

Considerando que Instagram es una red de referencia social para ellos, su tarjeta de visita y el escaparate donde exponen y modelan su propia imagen, estimé pertinente incluir una pequeña reflexión hacia esta plataforma y los modos de uso. Algunas de sus respuestas fueron muy esclarecedoras en lo que significa pertenecer a esta red y creo que a ellos también les sirvió para mirar de frente esta herramienta y sus implicaciones.

\section{Estas fueron algunas de sus reflexiones:}

“[...] En mi caso, Instagram no me ha hecho creerme superior a nadie ni pensar que por subir ciertas fotos con muchos "likes" me iban a hacer más popular o que la gente me idolatrara, al contrario, Instagram me ha hecho darme cuenta de la" literalmente" MIERDA de personas que hay por ahí, me ayuda a ver el comportamiento de otras personas que no debo tener yo, ayuda a que la construcción de mi " yo" tenga filtros de comportamientos negativos, de ideologías que no quiero tener etc. Por ello digo que en mi caso si ha sido positivo el uso de esta red social ya que me voy mostrando cada día tal y como soy, mis pensamientos sin tapujos y puedo mostrar tanto mi felicidad como mi tristeza, ya sea a través de los dibujos o de una fotografía de un bonito día en el campo, momentos divertidos con amigos o cualquier otra cosa. En mi opinión, la función que juega Instagram en nuestra identidad va a depender de cada persona, de lo que quiera mostrar y quiera creer de aquello que muestra y de la cabeza que tenga, porque esta herramienta para mostrar tu vida puede ser muy buena para encontrarte, buscar la inspiración que necesitas en otras personas y mostrar tu creatividad o puede ser perjudicial para ti y para tu mente y puedes llegar a caer en un bucle de ti mismo que te llegaría a ocurrir lo mismo que a Narciso."

“En mi opinión podría hacer una equivalencia con el lago en el que se refleja Narciso y se queda enamorado de si mismo, con las personas mirándose a las pantallas en Instagram, usando filtros de belleza, Photoshop, efectos de iluminación para verse perfecto. Nuestro Instagram no es 
nuestro verdadero yo, es un 'yo' ideal, una pequeñísima parte de nosotros que no es fiel siempre a la realidad. Sí que es cierto que es una herramienta reguladora debido al nivel de exposición entre unos y otros, lo que también puede causar una rivalidad, envidia, inseguridades etc, sentimientos vulnerables que ponen en duda y cuestionan quienes somos, cuanto valemos etc. Es una herramienta que puede jugar mucho en tu contra, puedes crear una imagen de ti inexistente para satisfacer tus miedos e inseguridades y sentirte así 'aceptado' por una sociedad que tiene unos cánones y parámetros muy concretos. Si lo usamos para restaurar una imagen lamentable de nosotros del plano de la realidad, puede que sea porque no estamos satisfechos con el 'yo' que creemos que somos y con el 'yo' que se expone a la realidad. Cuando tú estas conectado y aceptas tu imagen no tienes que huir, ni demostrar nada."

"He estado pensando varios días en esa pregunta, y la verdad que he llegado a la terrible conclusión de que Instagram nos "ayuda" a restaurar y darle "fuerza y consistencia" a nuestra imagen en la realidad. He llegado a la conclusión de esto porque sí que es verdad que cuando te incorporas a un nuevo grupo de gente o conoces a alguien nuevo e intercambiáis vuestros perfiles, cuando tienes la primera apariencia de una persona, puedes "modificarla" al menos un poco con su respectiva cuenta, ya que estarás conociendo aquello que el sujeto quiere que veas a través de su perfil. A partir de eso, ir conociendo sus gustos, el tipo de fotos que comparte,sus ideologías etc.. irás creando en tu cabeza un perfil de persona que podría no asemejarse al tipo de persona que podrías haber creado en tu cabeza si no conocieras esta cuenta en Instagram. $[\ldots]^{\prime \prime}$

“---, estoy muy de acuerdo con lo que dices del poder que tiene Instagram de condicionar el hecho de conocer a alguien en base a su perfil. Creo que, como dice ---, esta red social te da un punto de partida bien definido a la hora de conocer a alguien. Al revisar el perfil de la persona en cuestión puedes saber dónde ha pasado sus últimas vacaciones, cómo viste y cómo vestía, la música que le gusta escuchar y un largo etcétera.

Toda esta información te condiciona la forma de ver a esa persona, partes desde un punto del camino muy distinto al que hubiese sido si no se intercambiasen las redes sociales. Es muy distinto hablar y establecer relaciones sociales desde la pura ignorancia de la vida del otro (que puede llegar a ser incluso mágico ir conociendo poco a poco a dicha persona) que partir de una base de conocimientos sobre los gustos y estilo de vida del otro. [...]"

“[...] normalmente siempre seguimos a nuestro círculo de personas cercanas, pero además, este narcisismo del que hablamos y estos cánones tan establecidos en la red social, normalmente se muestran como un producto idealizado e irreal en forma de personas , no es más que publicidad para crear un inconformismo continuo en quien sigue a estos "influencers", de ahí que cada vez haya más, más competitividad absurda, y personas más "perfectas" en esa realidad que es Instagram. con lo cual, nosotros decidimos si seguirlos y entonces aparecernos en mayor o menor medida.

En mi caso, con el paso del tiempo me he dado cuenta de que seguía ese tipo de cuentas por convención social o simplemente por inercia. El contenido que me interesa ver hoy en día es 
muy distinto, me centro mucho más en lo que me aporta algo y me inspira, dejando atrás esa información vacía. Por otro lado, lo que decidimos mostrar en un primer momento creo que está relacionado con aquello que consumimos. De cierta manera, la mayoría de personas que están en Instagram pretenden, consciente o inconscientemente ser una especie de copia de estas personas tan influyentes en la sociedad, ya sea por que les inspira o porque saben que siguiendo ese patrón tendrán mayor aceptación social. Aquellas publicaciones de personas que por alguna razón se salen de ese patrón suelen resultar chocantes. A mí, personalmente, me suelen resultar más atractivas estas segundas cuentas, ya sea porque no se guían por los patrones establecidos o muestran una parte de lo que son mucho más interesante. [...]"

"Estoy totalmente de acuerdo con lo que ha dicho ---, Instagram no hace más que perpetuar los estereotipos y cánones en relación al cuerpo y al estilo de vida. Es la elección de cada uno seguir aportando un granito de arena al patrón establecido, o salirse de las bases de lo normativo."

"Yo por ejemplo, apenas la utilizo para algo que no sea ver cosas relacionadas con famosos. No subo normalmente contenido ni tampoco suelo ver el del resto a no ser que realmente tenga algún interés concreto en dicha persona o profesión. Por ello y abordando el

tema de los likes o los seguidores, me parece algo a lo que realmente no se debería de dar tanta importancia como algunas personas lo hacen. Siento que aquellos que se fijan en ese tipo de detalles tienen algún tipo de complejo o necesidad de atención. [...] Aunque por otro lado hay gente que vive de este tipo de cosas, los llamados "influencers" básicamente lo consideran su trabajo y eso es algo que respeto y puedo llegar a entender."

“Creo que es un eslabón perfecto para la divulgación de información, tanto buena como mala, he de admitir que gracias a Instagram he ido interesándome cada vez más en el activismo, sobre todo del feminismo y su importancia; pero creo que la clave de esta red social es utilizarla como un apoyo, como una pequeña pista de lo que luego tú por tus medios (ya sea leerte un libro o ver un documental y conferencias) consumes por y para tu crecimiento personal real; que es lo que verdaderamente formará tu identidad. Si abandonamos la vida real por así decirlo y solo consumimos información de estas redes, acabaremos siendo personas vacías con una "identidad de cartón" fácil de romper, porque no la habremos construido nosotros, habremos dejado que nos la construyan unos patrones y un sistema."

“[...] mucha gente sigue creyendo que una fotografía es (en términos generales) objetiva. Todos sabemos que no es del todo así, sin embargo, se desconoce hasta qué punto se puede subjetivizar la imagen. La cámara, que en este caso actuaría como impresión instantánea del espejo o de la "no-realidad", puede cambiar la aparente objetividad de un cuerpo, de un físico, o incluso de algo que nos queda muy cerca, un dibujo. Se vuelve muy complejo calificar las cosas cuando pasan por el filtro de la cámara, o del espejo. Lo ideal y lo que se busca es darle siempre más valor, acercándolo más a lo se espera en sociedad. Es un poco lo mismo que busca el maquillaje o la moda que sería resaltar los atributos que nos parece que nos aportan más valía como ser humano." 
“[...] una razón lógica por lo que la gente, hablando sobre todo de las/los influencers con más seguidores, enseñan su parte más feliz o de" vida ideal" ocurra porque se hace más sencillo publicar una foto en una playa paradisíaca, por ejemplo, que exponiéndote totalmente a la gente con una foto más negativa o contando algún problema ya que la repercusión que generaría sería totalmente distinta."

“[...] Instagram es una red social donde mostrar los sentimientos que nos hacen humanos está mal, como el miedo, las inseguridades, tener malas rachas, la tristeza etc. Y es cierto que esto te limita, en mi caso cuando me siento mal conmigo misma ver esta red social me hace sentir peor, dudo que sea la única, a pesar de ser consciente de que lo que vemos no es toda la realidad. Esta 'toxicidad positiva' es Instagram, el Mr Wonderful diario, porque la realidad no es así, y esta red social a veces simplemente potencia que te sientas agobiado por la obligación de tener que estar feliz y igual de productivo, deportista, sano y guapo que el perfil de la persona que has visto una vez en la vida."

"[...] en cierto modo se crea ese mercado de imágenes en el que se busca ese equilibrio entre mostrarte tal como eres, fiel a esos "principios", y seguir las pautas, como dice ---, de ese mercado, el ser "aprobado" socialmente."

“[...] al fin de al cabo es esto lo que pretendemos conseguir. Likes. Aprobación. Nos vendemos en mayor o menor medida por ellos. Incluso calculamos la hora a la que más gente llegará nuestra publicación para conseguirlos. Entonces ¿Es cierto que construimos nuestra identidad en base a esta especie de mercado que es Instagram? Yo creo que es algo evidente a pesar de que la mayoría del tiempo no nos demos cuenta o ni siquiera tengamos la intención."

“[...] Pero, ¿evolucionamos con nuestras publicaciones por nosotros mismos o por dejarnos llevar por toda esa información y contenido que consumimos? En el cuento de Alicia en el país de las maravillas muchas veces se preguntaba ¿quién o qué soy yo? y ella no sabía responder. ¿Alguna vez habéis pensado esto viendo vuestras propias publicaciones y siendo críticos con uno mismo?"

"Instagram es una red social que nos identifica. En estos tiempos, si no tienes Instagram, no eres nada. Cuando conocemos a alguien, intercambiamos nuestros nombres de usuario en vez de nuestros números, así es como enseñamos un yo público que queremos que sea visto, aunque no sea el real. En mi caso, empecé en esta red con 12 años, al igual que mis amigos de ese momento. Todos empezamos subiendo fotos de nuestros amigos o mascotas. A medida que crecemos, vamos construyendo nuestra personalidad, [...]. Nuestras fotos también van cambiando al igual que nuestra manera de pensar y de ver instagram. Aquellas imágenes en solitario, al igual que las fotos "selfies", se plantean de otra manera a la hora de ser realizadas, [...]. Pensamos en nuestro mejor apariencia para enseñar nuestra mejor cara, una cara afable, sin ningún mal, a veces intimidante, a veces sonriente... Así pues aumentando el ego y aceptándose con cada 'like'." 
Como en el retrato de Dorian Grey, Instagram puede favorecer una obsesión por la imagen y la estética, pues las opciones que ofrece la herramienta están enfocadas a potenciar la presencia en la red. En los comentarios de los estudiantes se puede ver lo que para muchos de ellos supone formar parte de esta comunidad virtual, pues como dice una alumna, "si no tienes Instagram no eres nada". También es llamativo comprobar lo importante que es el perfil para conocer al otro o te conozcan. Como dice otra alumna, gracias a él puedes completar la identidad de una persona que se acaba de conocer.

A pesar de que el foro propone un pensamiento crítico ante esta plataforma y estoy segura de que el hecho de planearse preguntas les ha ayudado a entender mejor lo que tienen entre manos, Instagram es demasiado poderoso y atractivo como para dejar de mirarlo. Como expresa muy bien otra estudiante "Instagram es el lago de Narciso".

\section{Propuestas plásticas}

Además de las referencias ofrecidas, las lecturas para la realización del análisis y la participación en el foro, también les propuse unas pautas de trabajo donde debían de poner en marcha sus destrezas plásticas.

Las pautas que elaboré no podían tener unas restricciones muy cerradas, puesto que, como he comentado anteriormente, muchos de los estudiantes no contaban con apenas material debido a la situación. Como a fin de cuentas todos tenemos un espejo en casa ya sea grande o pequeño, planteé una práctica de dibujo a partir de su imagen reflejada. Podían trabajar el cuerpo entero o fragmentado y utilizar las herramientas de manera más realista o más expresiva con el material que dispusieran. Solo tenían la limitación de que debían entregar tanto dibujos a línea como a mancha.

Aunque en las pautas indiqué que trabajaran el cuerpo ya fuera entero o fragmentado, muchos de ellos se centraron en el rostro; quizás porque para cada uno de nosotros, el rostro es lo que más nos define y distingue, además de centralizar las expresiones más sutiles. Si bien hubo quienes trabajaron con el fragmento y con otras zonas del cuerpo, el rostro fue el gran protagonista. 
Como propone Tonia Raquejo en su texto, el espejo abre un no-lugar donde el espectador se plantea la cuestión de lo real y lo ficticio. Con esta idea de fondo, algunos de ellos introdujeron en el propio dibujo el marco del espejo, creando así dos o más espacios en la misma lámina y otros directamente eliminaron el límite del espejo creando así una ambigüedad en el dibujo entre lo ficticio de la representación real y lo ficticio de la representación del reflejo.

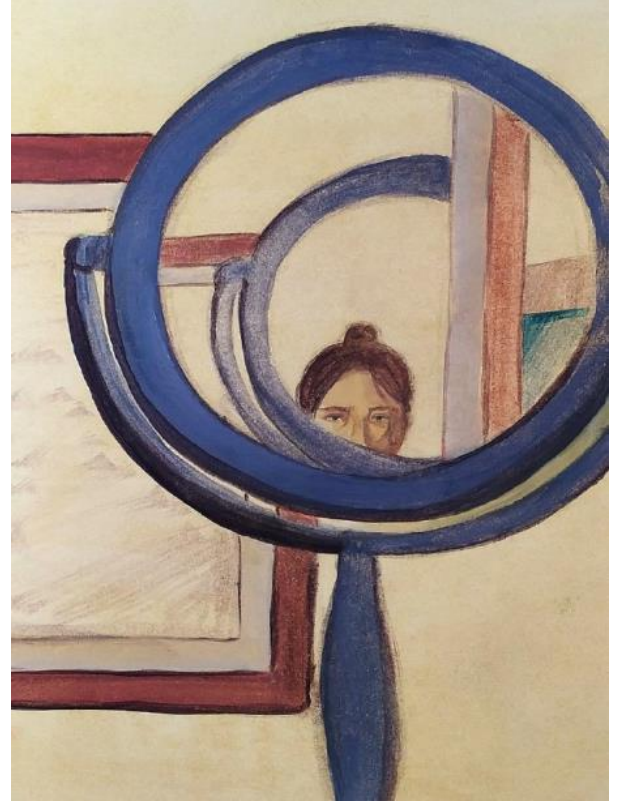

Mora Romero. Abril.2020. Espejo. Mixta.

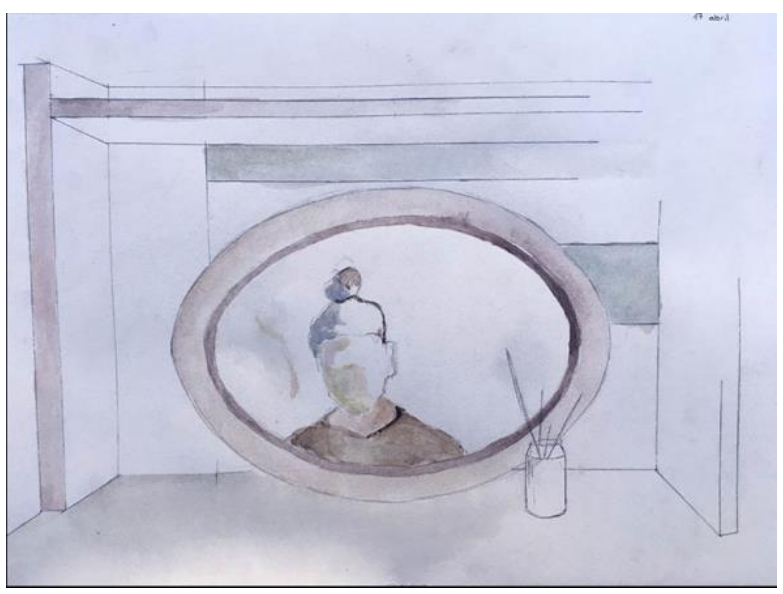

Ana Cruañes. Abril.2020. Espejo. Acuarela.

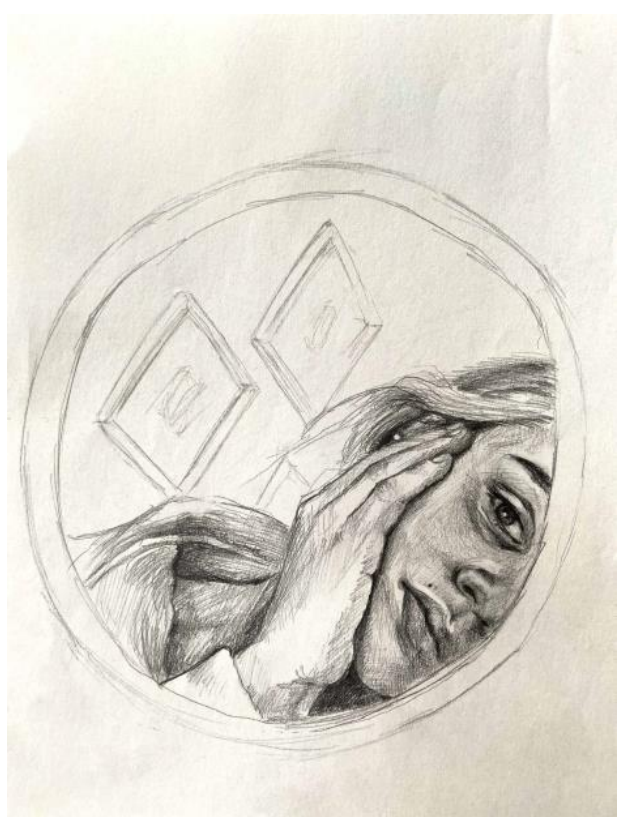

Victoria Francia. Abril 2020. Espejo. Grafito.

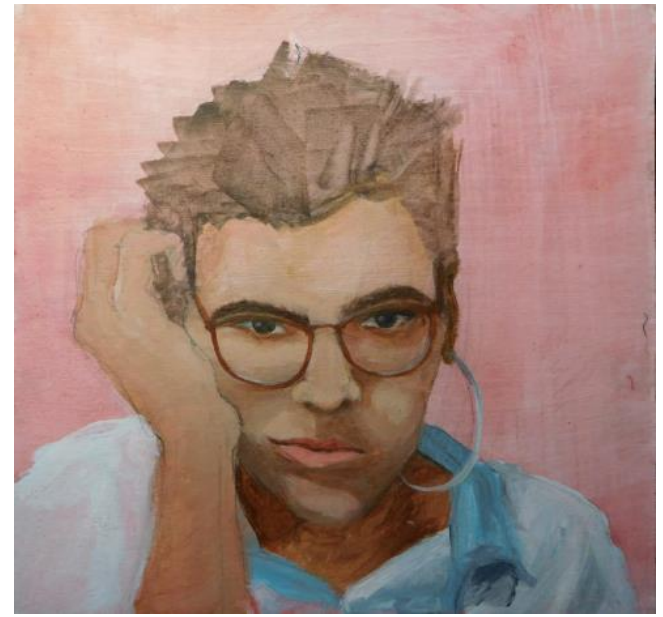

Paloma de Miguel. Abril 2020. Espejo. Acrílico. 
Asimismo, he encontrado enfoques que son estudios de la técnica y enfoques más lúdicos. Puesto que les di unas pautas muy abiertas, cada uno tuvo la libertad de dirigir el trabajo hacia sus intereses más personales y ofrecer no solamente un resultado sino el reflejo de un interesante proceso.

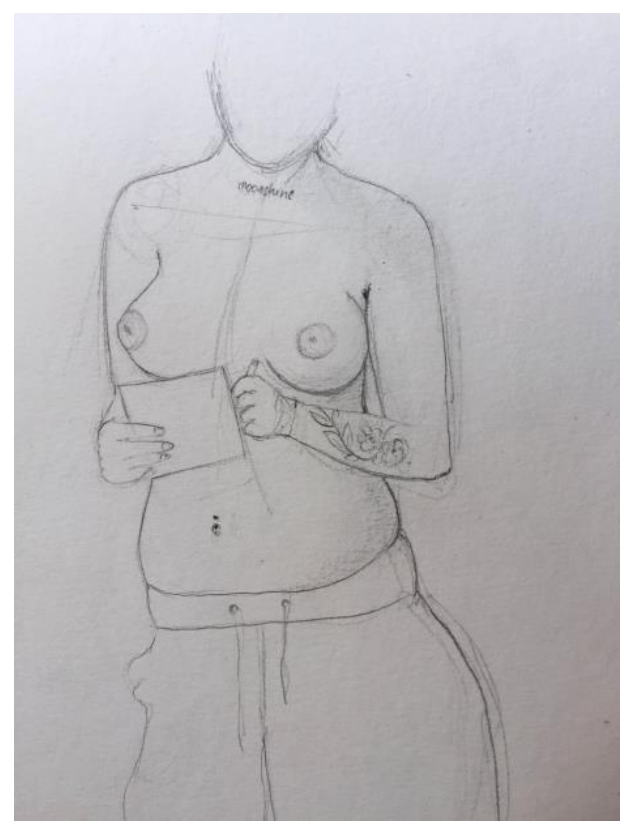

Nerea Sánchez. Espejo. Grafito. Abril 2020

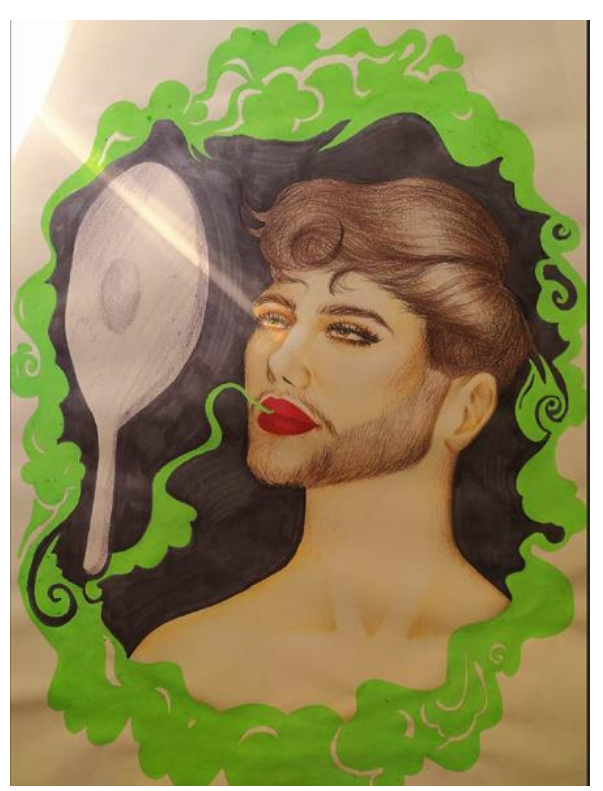

Fran Lorenzo. Abril 2020. Espejo. Mixta.

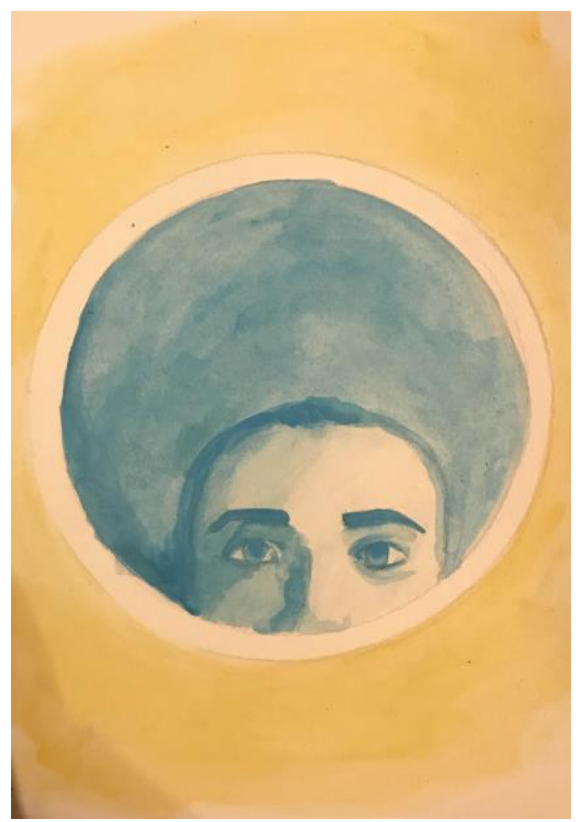

Marina Robles. Espejo. Acuarela. Abril 2020

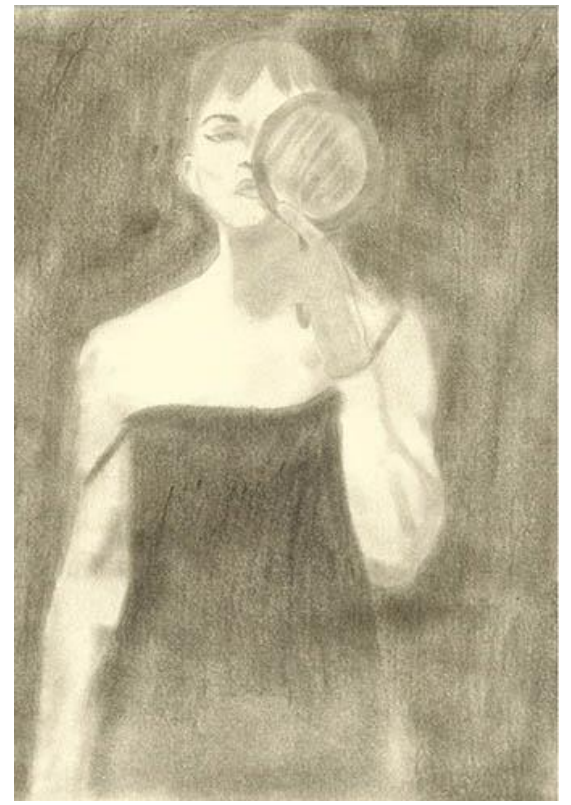

Jesús Rey. Abril 2020. Espejo. Carboncillo. 
No se puede olvidar tampoco que venimos de una tradición en el arte donde muchos artistas se han retratado ante el espejo ellos mismos rodeados de su atmósfera de trabajo. Algunas estudiantes han seguido esta pauta de una manera más o menos intuitiva, pero en todo caso seguidora de esa tradición del artista ante el espejo.

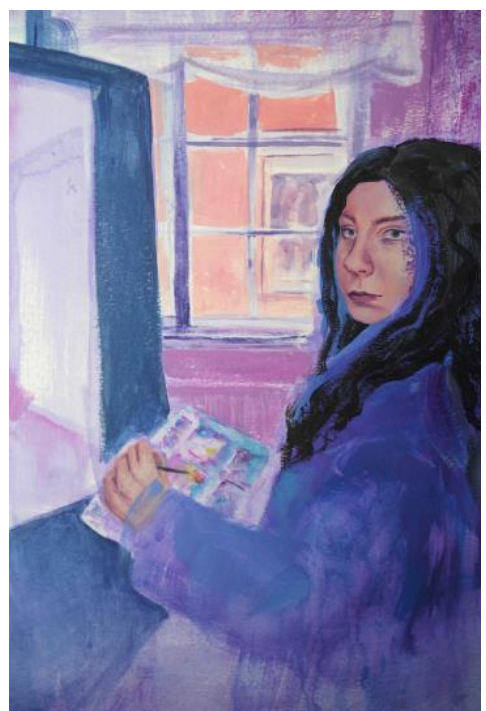

Lydia Gordaliza. Abril 2020. Espejo. Acrílico.

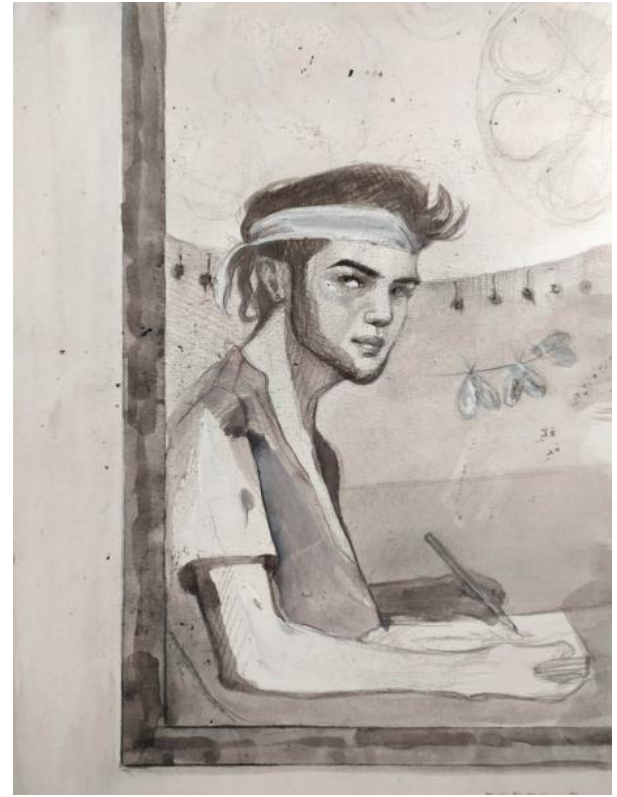

Fran Lorenzo. Abril 2020. Espejo. Mixta.

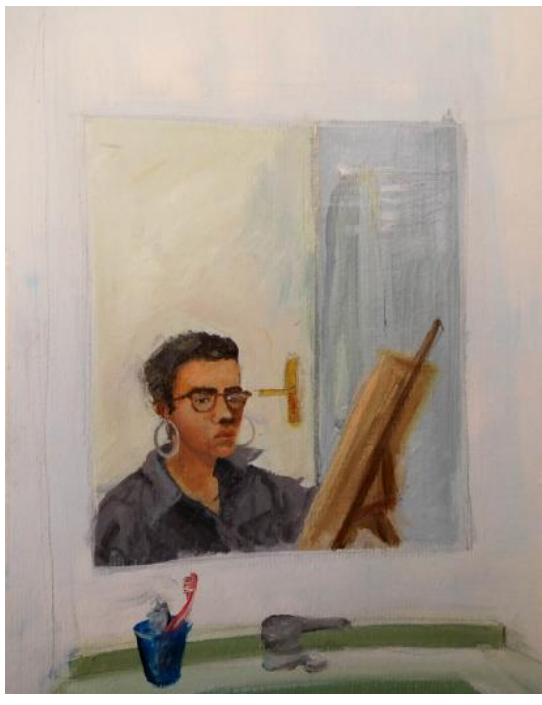

Paloma De Miguel. Abril 2020. Espejo. Acrílico.

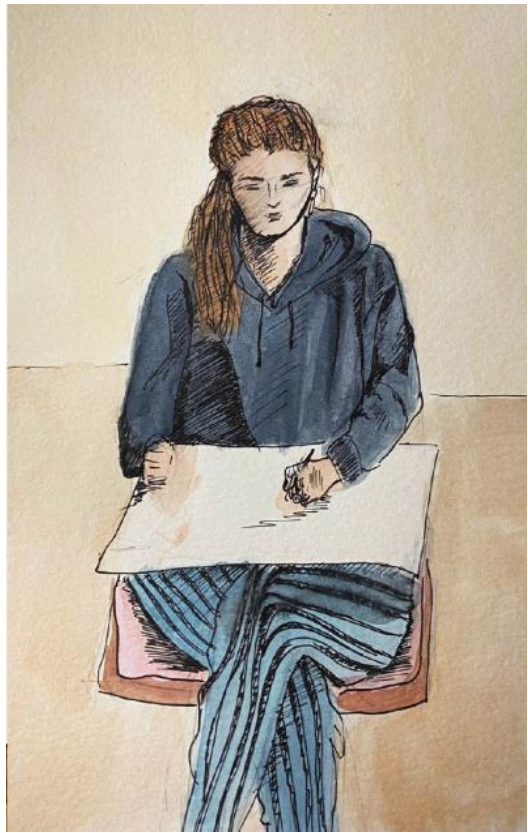

Patricia Mohedano. Abril 202. Espejo. Mixta. 
Como se puede ver, cada uno se llevó las pautas al terreno que quería resaltar. Algunos trabajaron más el estudio de los espacios real y reflejado, otros más la propia figura dejando de lado el espacio y otros se centraron más en lo que podían ofrecer los recursos plásticos - la herramienta, la composición, el trazo, etc-. Todos ellos formando un conjunto muy diverso en la forma de enfocar el trabajo.

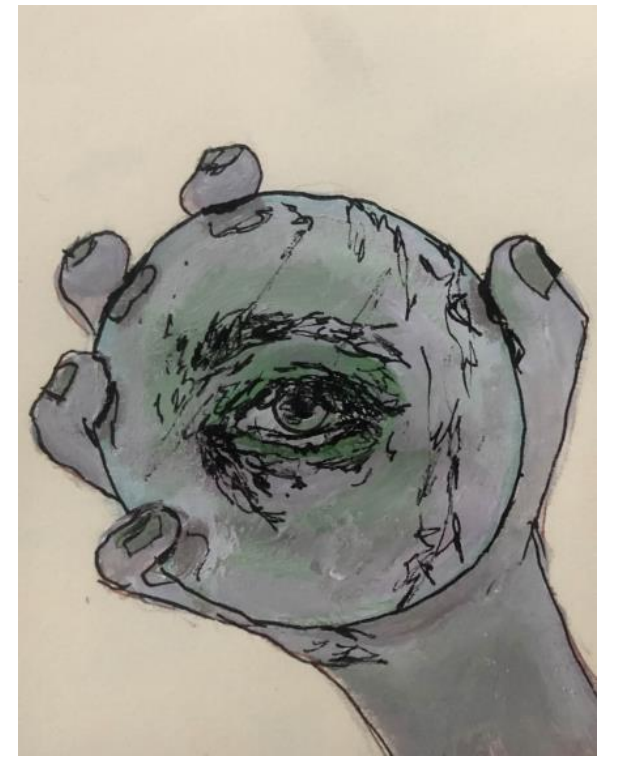

Livia Marcondes. Abril 2020. Espejo. Mixta.

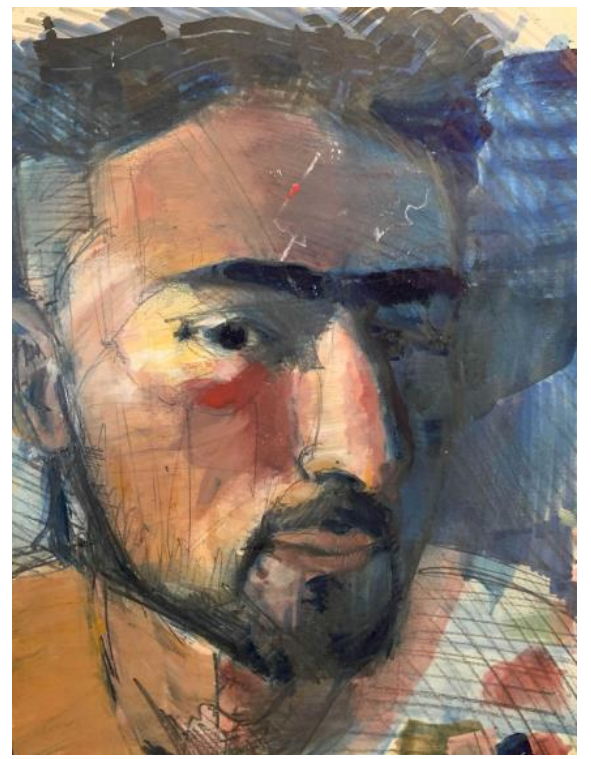

Julián Recchia. Abril 2020. Espejo. Mixta.

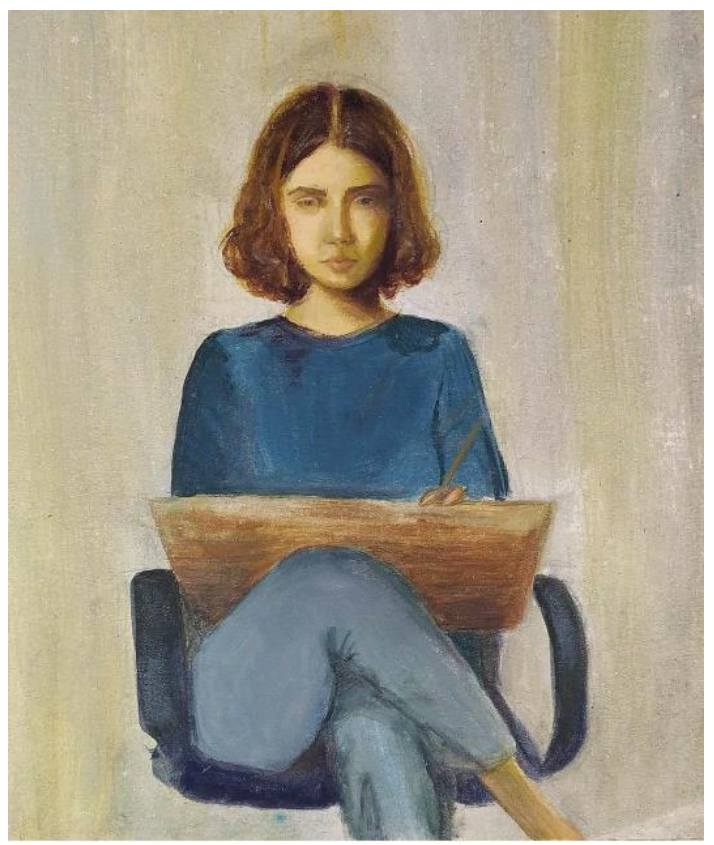

Mora Romero. Abril 2020. Espejo. Acrílico. 
Para complementar el trabajo de dibujo ante el espejo, les pedí también que interpretasen plásticamente el mito de Narciso. Ya habían leído y analizado el texto del escritor Roger Graves para el trabajo de análisis y ya habían reflexionado tanto en el análisis como en el foro sobre el encantamiento de la imagen propia, por lo que contaban con recursos conceptuales básicos para poder sacar sus propias imágenes. Como comenté anteriormente, también ofrecí para el que quisiera la lectura más analítica de Jacques Lacan y la novela de Oscar Wilde, la cual es tan plástica y tan cercana al mito de Narciso que era prácticamente obligada su presencia entre el material de apoyo, aunque fuera una lectura voluntaria.

En este segundo trabajo encontré tantas interpretaciones del relato como autores. Un texto traducido al lenguaje abierto del dibujo consigue ofrecer muy diferentes expresiones, tanto en la ejecución como en el mensaje de fondo. Como he comentado anteriormente, estos estudiantes son de primer curso, lo cual significa que están empezando a profundizar en el leguaje plástico y visual, aunque algunos vengan de formaciones artísticas previas. Esto significa que si bien sus propuestas están en un nivel de iniciación, los resultados han sido muy interesantes gracias a la frescura del enfoque que cada uno ha dado ${ }^{1}$.

Entre las propuestas recibidas he encontrado orientaciones de Narciso hacia la melancolía, la sensualidad o incluso la rabia. También los ha habido que han aprovechado para castigarle por su falta de empatía hacia aquellos que abandonó por el camino. Hay Narcisos donde está muy potenciado su carácter narcisista - valga la redundancia- o donde queda envuelto en una cierta mística. Hay algunos que lo perdonan y otros que casi se regodean en su muerte, pero la gran mayoría de ellos centra su trabajo en el momento que se mira en la superficie del lago. El relato es extenso e introduce a otros personajes, pero es tan poderoso y dramático el encuentro con su reflejo que es comprensible la atracción hacia esta escena. Asimismo, y como he comentado, el nivel de formación de estos estudiantes todavía les lleva a trabajar en la literalidad, aunque el mito trate de cuestiones que van más allá del propio relato. Sin embargo, ya se atisba en esta literalidad un trabajo más simbólico que poco a poco les irá llevando a propuestas más abiertas. A mi juicio, muchos de estos resultados ofrecen señales de que así va a ser más adelante.

1. Aunque este no sea el foro para tratar la cuestión del acercamiento del artista a su obra, quiero señalar que los alumnos de los primeros cursos reflejan una inmediatez y una franqueza en sus trabajos que con la experiencia a menudo se pierde en aras de otras capacidades e intereses. Saber combinar la franqueza y la frescura con la pericia es seguramente una de las competencias más preciadas. 
A continuación, presento una selección de trabajos.

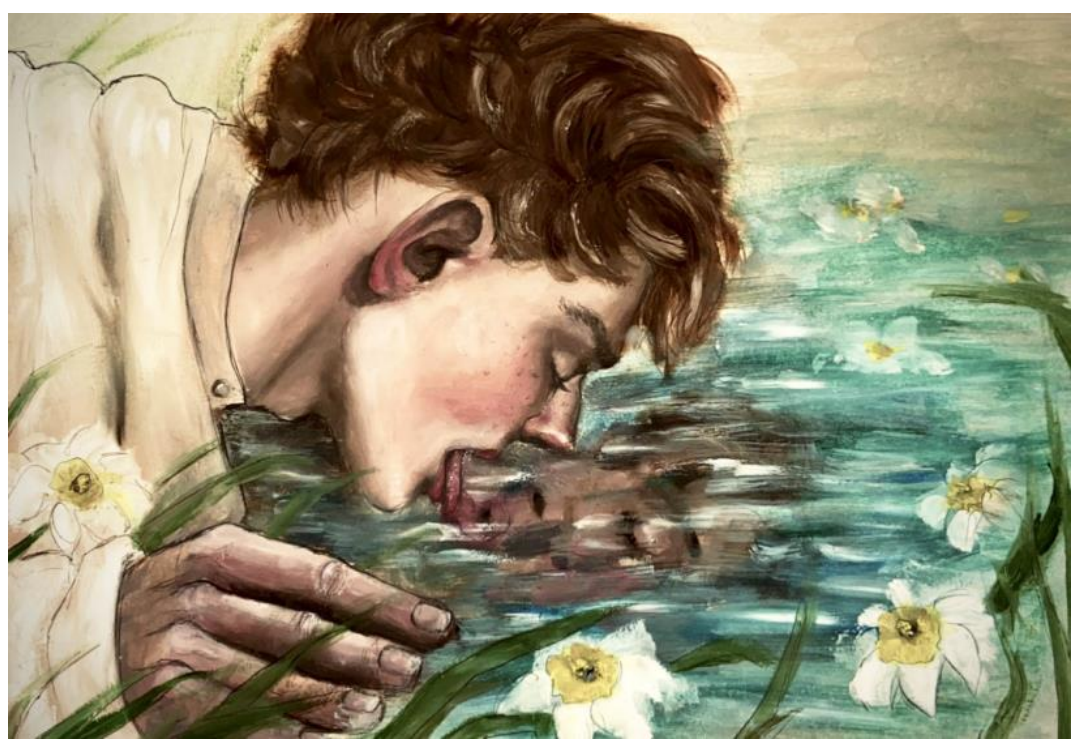

Victoria Francia. Abril 2020. Mito de Narciso.
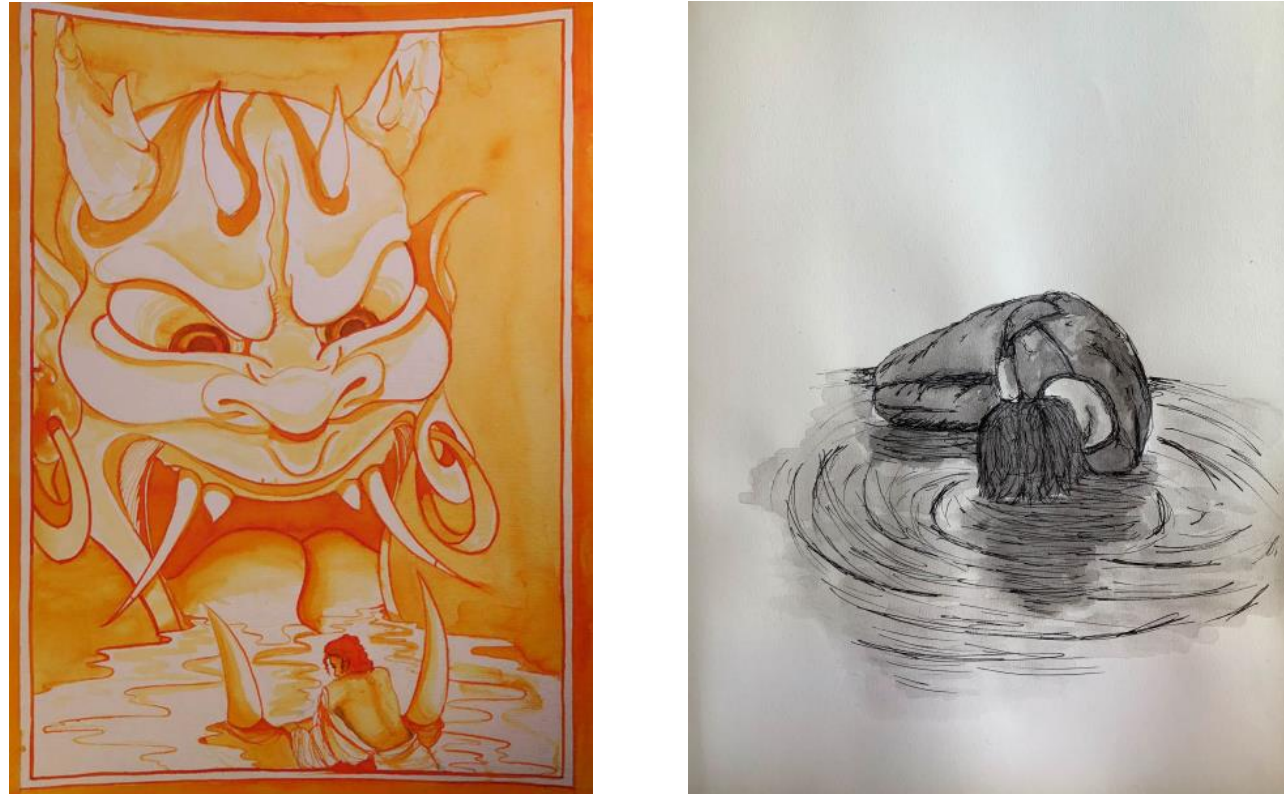

Paloma de Miguel. Abril 2020. Mito de Narciso.

María Gómez. Abril 2020. Mito de Narciso. 


\section{Tercio Creciente}

DOI: https://dx.doi.org/10.17561/rtc.extra4.5733 Investigación
Monográfico Extraordinario IV

Lugares y No Lugares para la creación Diciembre 2020

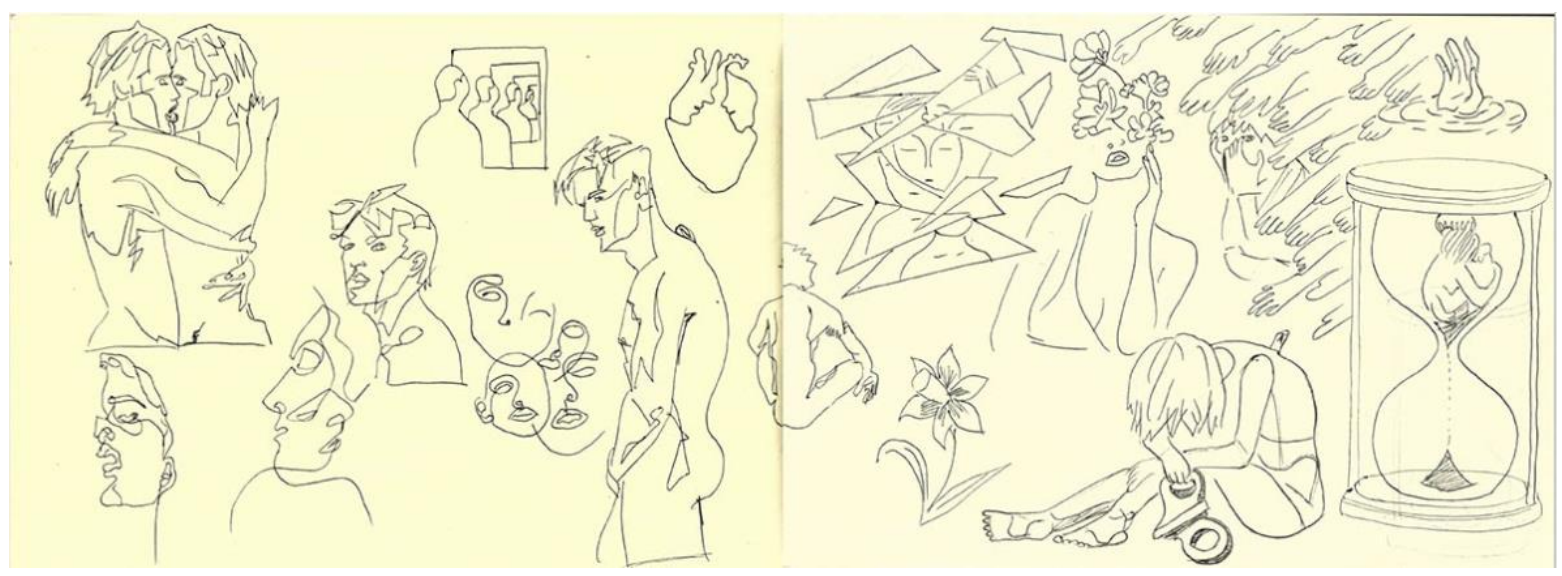

Jesús Rey. Abril 2020. Mito de Narciso.

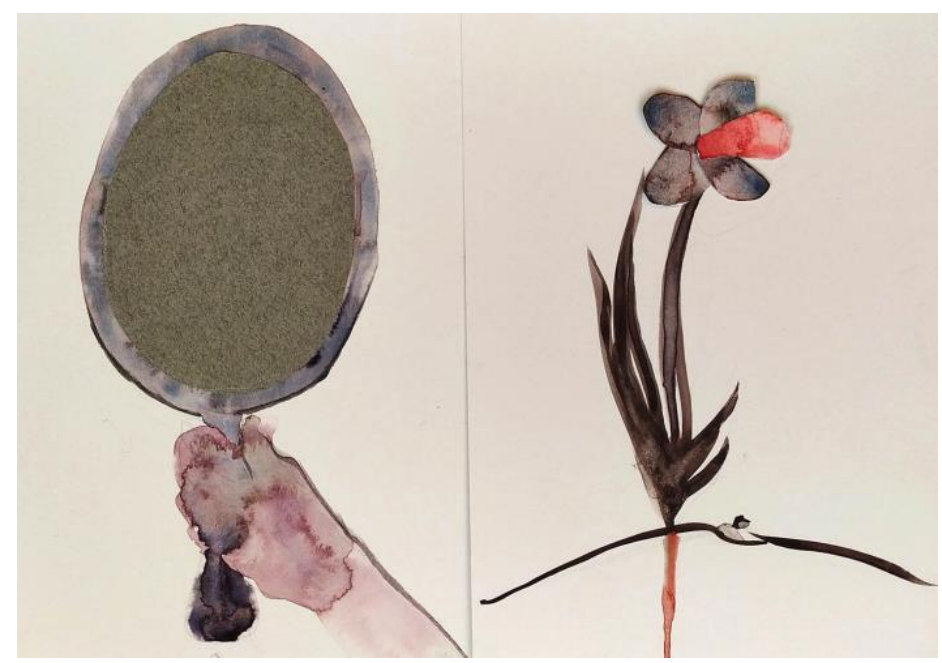

Mora Romero. Abril 2020. Mito de Narciso. 


\section{Tercio Creciente}

DOI: https://dx.doi.org/10.17561/rtc.extra4.5733 Investigación
Revista de Estudios en Sociedad, Artes y Gestión Cultural ISSN: 2340-9096
Monográfico Extraordinario IV

Lugares y No Lugares para la creación Diciembre 2020
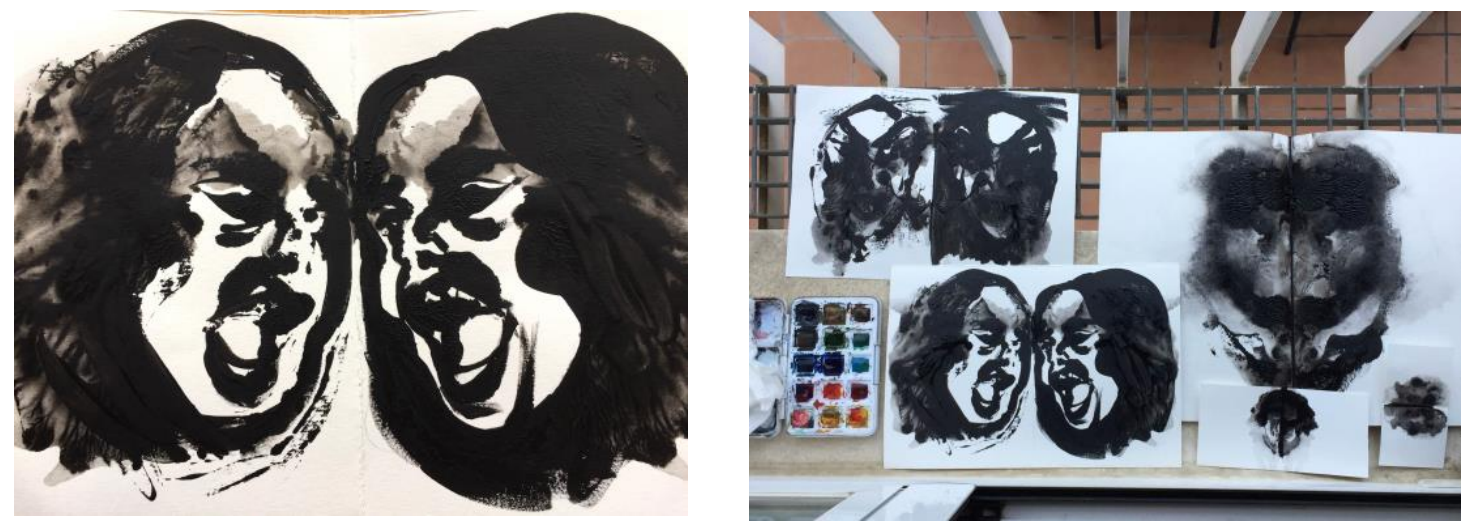

Nerea Sánchez. Abril 2020. Mito de Narciso (imagen y proceso).
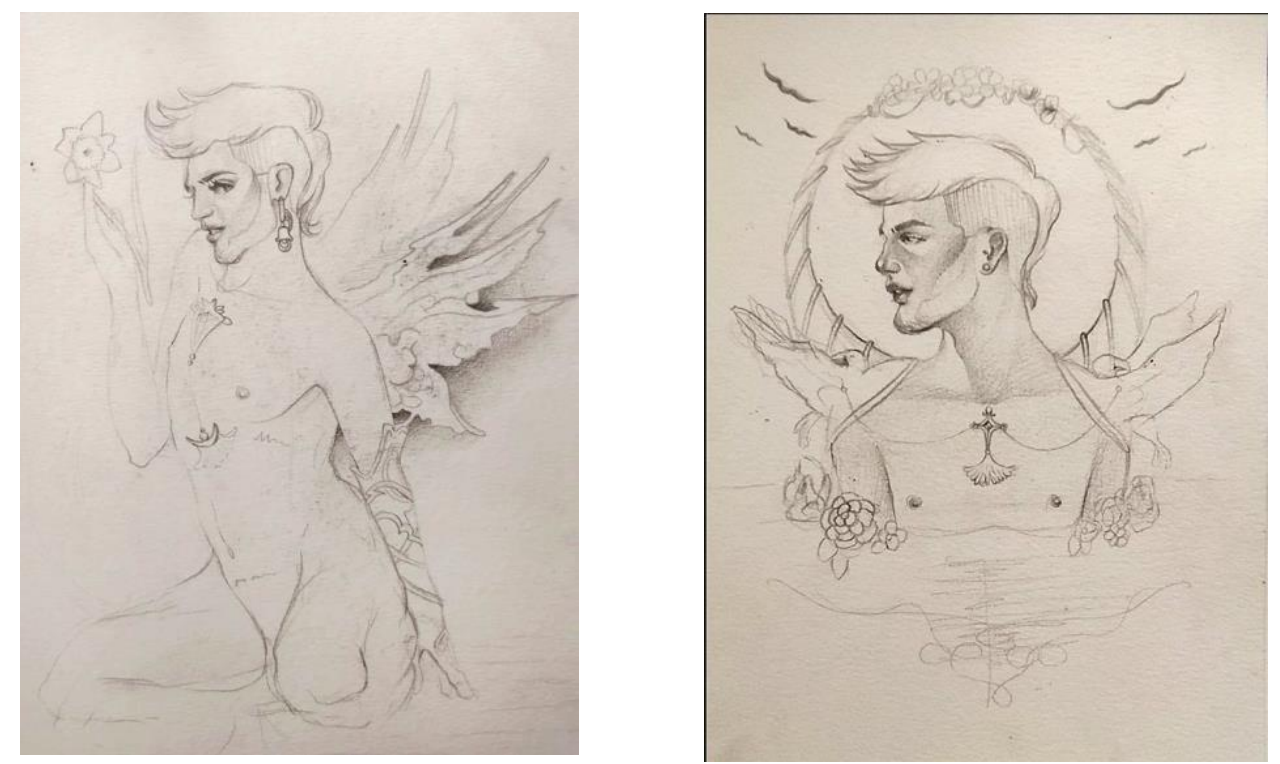

Fran Lorenzo. Abril 2020. Mito de Narciso. 


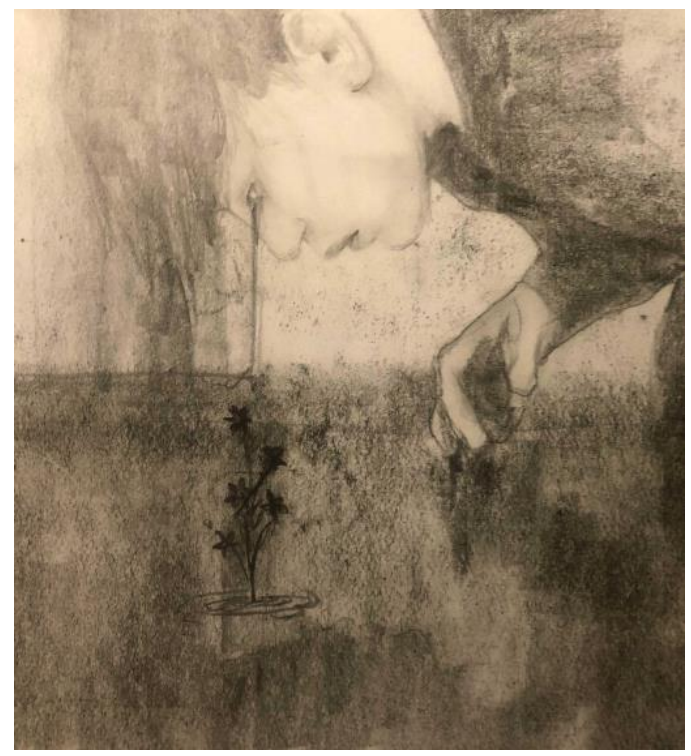

Livia Marcondes. Abril. 2020. Mito de Narciso.

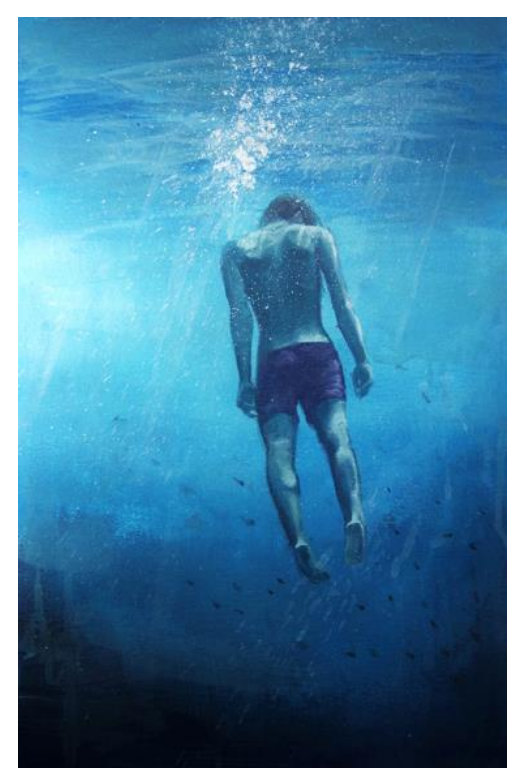

Lidia Gordaliza. Abril 2020. Mito de Narciso.

\section{Conclusiones}

Como ya he comentado a lo largo del texto, la experiencia de trabajo con este grupo de primero ha sido excelente. Sin embargo, mi sensación general es en cierto sentido amarga debido a que sostengo, y esta experiencia no me hace cambiar de idea, que no hay sustituto al contacto real con las personas. Oigo decir a menudo que las nuevas formas de enseñanza on line han venido para quedarse y que esta situación ha acelerado algo que poco a poco se estaba ya imponiendo. Puede ser. Es cierto que yo misma prolongo mi enseñanza en el Campus Virtual y todos los estudiantes a los que doy clase saben que deben visitarlo para seguir correctamente la asignatura. Pero encontramos situaciones en la enseñanza que no hay tecnología que las reemplace. Existen herramientas muy depuradas para tener un contacto directo con el estudiante como hemos podido comprobar en estos meses, pero no deja de ser una relación a través de una pantalla y muy mediatizada por las condiciones técnicas.

Gracias al esfuerzo que la Universidad ya venía haciendo en la adaptación tecnológica hemos podido salvar el curso propiciando además experiencias nuevas y muy enriquecedoras como la que este grupo de estudiantes y yo hemos vivido, sin embargo, ojalá nada de esto hubiera pasado. Ojalá hubiera podido desarrollar esta 
actividad dentro de un marco de enseñanza presencial, pues creo que a día de hoy la modalidad on line desactiva muchos de los procesos que se crean en un entorno de enseñanza presencial y directa. Soy de la opinión de que el éxito en la labor docente pasa por el clima y la atmósfera que creamos el grupo completo cuando nos encontramos en el aula. A día de hoy la docencia a través de los dispositivos digitales es una gran ayuda y puede salvarnos de situaciones sobrevenidas como esta, pero de ningún modo puede ser un sustituto al no contar con aspectos esenciales y necesarios en esta labor.

Por otro lado, ya he comentado que fue una grata coincidencia que el bloque relacionado con el cuerpo lo viéramos justo en el momento que tuvimos que encerrarnos. Efectivamente creo que la reflexión que los estudiantes han realizado en torno a su imagen y a sí mismos se ha visto favorecida por esta circunstancia, pues el aislamiento ha podido ayudar a mirarse con más tiempo y calma. Uno de los alumnos me escribió un correo diciendo que agradecía mis comentarios en el trabajo del espejo, dado que se sentía muy inseguro al exigirse cada vez más. Yo imagino que precisamente esa exigencia y esfuerzo vienen de vivir un desacostumbrado contacto consigo mismo, tal como nos ha pasado a todos en las semanas del confinamiento más estricto.

Otros alumnos me escribían preocupados por su situación, pues en algunos casos su condición personal previa ya era complicada y esto no ha hecho más que endurecerla. Esta nueva forma de trabajar en la distancia ha propiciado que las circunstancias personales hayan tenido una presencia muy importante en el proceso, a pesar de no haber tenido contacto directo. Supongo que esto se debe a que hemos necesitado suplir la información que se recibe en la presencialidad con otra más explícita del estado de cada uno, pues este modo de enseñanza produce muchos vacíos que es necesario llenar de alguna manera.

En lo relativo al propio trabajo, creo que la mirada reflexiva es un ejercicio yo diría obligado para avanzar como artistas. En esta práctica he intentado ofrecer claves que en un futuro pueden ayudar en un trabajo de introspección más profundo y largo en el tiempo. Por otro lado, he observado que para muchos de estos estudiantes el ejercicio ha significado una nueva forma de mirarse y entenderse, pues al acoplar su trabajo con el de otros artistas, lecturas y compañeros han podido realizarlo en un plano menos ensimismado y más objetivo. Creo que el hecho de diversificar los recursos y colectivizar los procesos y resultados ha podido ayudar en el progreso del grupo hacia una consciencia de ellos mismos más madura.

\section{Referencias}

Aznar, S. y Martínez, J. (2009). Últimas tendencias del arte. Centro de Estudios Ramón Areces. 
Graves, R. (1985). Narciso. En R. Graves (Ed) Los mitos griegos, 356-359. Alianza Editorial.

Lacan, J. (2009). "El estadio del espejo como formador de la función del yo [je] tal como se nos revela en la experiencia Psicoanalítica". En Escritos I, pp. 99-105. Siglo XXI.

Raquejo, T. (2012). El espejo como no-lugar (1964-2010). Quintana (11), 243-258.

Wilde, O. (1989). El retrato de Dorian Grey (trad. Julio Gómez de la Serna) (3a ed.). Planeta. (Original publicado en 1890). 